\title{
The Use of Blended Cooperative Learning Model in Introduction to Digital Systems Learning
}

\author{
R. Ati Sukmawati ${ }^{1}$, Mitra Pramita ${ }^{2}$, Harja Santanapurba ${ }^{3}$, Bekti Utami ${ }^{4}$ \\ ${ }_{1,2,3,4}$ Department of Computer Education, Faculty of Teacher Training and Education, Lam- \\ bung Mangkurat University, Indonesia
}

DOI: 10.23917/ijolae.v2i2.9263

Received: November 20 ${ }^{\text {th }}, 2019$. Revised: December $11^{\text {st }}, 2019$. Accepted: December $26^{\text {th }}, 2019$

Available Online: January $2^{\text {nd }}, 2020$. Published Regulary: July $1^{\text {st }}, 2020$

\begin{abstract}
The purpose of this study is to analyze student learning outcomes in the application of the blended cooperative learning model, and analyze students' perceptions about the application of the cooperative blended learning model. Quantitative and qualitative research methods were used together with 91 subjects as participants in Introduction to Digital Systems academic year 2018/2019. Data was collected by tests, questionnaires, observations and video recordings. The results showed that the student learning outcomes were in the sufficient category. Students showed a positive perception of the implementation of the blended cooperative learning model, but they still need more encouragement to be more independent in learning.
\end{abstract}

Keywords: blended learning, cooperative learning, digital systems learning Corresponding Author:

Ati Sukmawati, Faculty of Teacher Training and Education, Lambung Mangkurat University, Indonesia e-mail: atisukmawati@ulm.ac.id

\section{Introduction}

Introduction to Digital Systems is a compulsory subject for students of the Computer Science Education Program at Lambung Mangkurat University. This subject is a prerequisite for advanced courses. But many students have difficulty with this subject. Generally the difficulty is caused by students lacking training and not having textbooks. Various attempts have been made by lecturers to optimize the learning process, including by applying the cooperative learning model. Cooperative learning model is a teaching and learning process that involves the use of small groups that allow students to work together in order to maximize their own learning and learning from each other. Students learn and work in small groups collaboratively, whose members consist of four to five people, with a heterogeneous group structure (Slavin, 1994).

The cooperative learning model is designed to prepare students to have an orientation to work in teams. Students not only learn the material, but must learn special skills called cooperative skills. In completing the task group, each group member must cooperate with each other and help each other to understand the material being studied. Learning is said to be incomplete if one of the friends in the group has not mastered the lesson material.

Limitation of study time in class is one of the obstacles faced by lecturers when applying cooperative learning models. This is in line with the results of research done by 
Sukmawati \& Purnamasari (2016) and Sukmawati \& Nesvihani (2018), which state that the time available is sometimes insufficient to implement cooperative learning models. The use of blended learning is expected to overcome these obstacles. Because in blended learning, interaction between students, or between students and learning resources can occur anytime and anywhere. This is in line with the Indonesian government's vision that educational institutions can utilize information and communication technology to improve the efficiency and effectiveness of learning, including by implementing blended learning.

Blended Learning is a learning approach that combines face-to-face activities, aspects of online learning and real-world practice (Husamah, 2014). Dziuban et al (2018) and Hall \& Villareal (2015) define that blended learning is learning that combines face-toface learning and integrated online-based learning. Learning is not only done in class but can also be done anytime and anywhere. So that the application of Blended Learning can overcome the limitations of space and learning time that occur in face-to-face learning in class. While Rusman (2012) also Gill (2009) state that blended learning is a combination of various media technology and information such as audio, video streaming, and website in an e-learning system path with face-to-face learning.

Blended Learning is a learning approach that combines technology and face-to-face learning. The purpose of blended learning is to combine the best characteristics of classroom learning (face to face) and the best features of online learning to enhance active independent learning by students and reduce the amount of face-to-face time in class (Graham, 2006). With computer-based technology, teachers use a hybrid learning model to redesign their subjects so that there are online activities in the form of case studies, tutorials, independent training, simulations or online group collaboration.

Blended learning focuses on changing the form of classical learning to make students more active in learning learning material in the classroom and outside the classroom (Husamah, 2014). The ultimate goal is to increase students' understanding of the learning material shown by increasing the value of the redesigned subjects.

Graham (2006) and Moskal et al (2013) state that blended learning has helped students to learn independently, shifted the paradigm of teacher center to student center, and the achievement of learning objectives. To obtain optimal results in blended learning, the teacher must have knowledge about learning strategies and know the characteristics of students. By knowing the characteristics of students, appropriate learning materials can be prepared, both online and offline. In blended learning, students will interact more with the learning material.

According to Friesen (in Nuruzzaman, 2016), blended learning in general can be classified into six models, namely: Face to face driver; the teacher conveys instruction and reinforcement through digital devices. Rotation; students follow the online learning cycle independently and learn face to face in class. Flex; most of the curriculum is delivered via a digital platform. Teacher guidance and support is done face-to-face. Labs; the entire curriculum is delivered via a digital platform but in a consistent physical location. Students usually take traditional classes in this model too. Self-Blend; Curriculum and learning are done face-to-face. Students add to learning through online learning. Online Driver; All curriculum and teaching are delivered via a digital platform. If it is needed a face-to-face meeting can be scheduled. Blended learning in this study is an adaptation of Gill (2009), namely a mix of face-to-face 
instruction in the classroom and instruction through digital technology. During face-toface sessions, students have the opportunity to discuss about the material and work that has been assigned in digital technology. After all clarifications have been made, the face-toface session continues with task-based learning.

The advantages of blended learning according to Meydanlioglu \& Arikan (2014) are the use of more flexible and effective learning spaces, maximizing the use of physical resources, and fostering academic excellence and innovation. In addition, students are to be able to increase the level of student autonomy that is more realistic (control and responsibility), increase their involvement and interaction. Content can be developed in a way that meets the needs and styles of various learners. The online component also encourages students' independence, facilitates self-reliance, and expands learning through the use of innovative online resources.

Meanwhile challenges faced in blended learning according to Meydanlioglu \& Arikan (2014) include: students must have time management skills, have physical resources (computers, high-speed internet), be able to play an active and collaborative role, learn to use more sophisticated technology, lack of friend contact and interaction. One major disadvantage is that effective online learning will need time to be implemented correctly.

Research conducted by Aspden \& Helm (2004) shows that blended learning can help bridge the gap between students, by means of interaction between students both online and offline as well as increasing the effectiveness of learning and teaching experiences for students. The results of the study done by ElDeghaidy \& Nouby (2008) of prospective teachers at the University in Egypt showed that cooperative blended e-learning was effectively applied in learning, where student learning outcomes in cooperative blended elearning classes were better than control classes. Meanwhile the results of the study done by Hima (2017) showed that blended learning can improve students' motivation. Similar conclusion is also found in the result of research conducted by López-Pérez et al (2011) at the University of Granada. In the finding of their research, the use of blended learning has a positive effect in reducing dropout rates and can increase test scores.

The purpose of this study is to analyze student learning outcomes in the application of blended cooperative learning models, and analyze students' perceptions about the application of the blended cooperative learning Model. The study was conducted in the Computer Education Study Program at the University of Lambung Mangkurat in the Introduction to Digital Systems course. This design is needed by the lecturer as a reference in preparing the lecture plan. So that it can implement student-centered learning, and can improve the effectiveness of learning.

\section{Method}

This study will describe student learning outcomes and perceptions about the application of the blended cooperative learning model in the Introduction to Digital Systems course. This research was conducted at the Computer Science Education Study Program Faculty of Teacher Training and Education, Lambung Mangkurat University, Indonesia. The study was conducted in February to May 2019. The subjects in this study were all 91 participants in the Introduction to Digital Systems course in the academic year 2018/2019. The research instrument used consisted of quiz sheets, evaluation sheets, questionnaires and observation sheets. The quiz sheet consists of three packages, each containing five short answer questions. The evaluation sheet 
consists of ten essay questions. The questionnaire consisted of seven positive statements that were designed using a Likert scale, with alternative answers strongly disagree (SDA), disagree (DA), neutral $(\mathrm{N})$, agree $(\mathrm{A})$, and strongly agree (SA). The instrument validity test uses Pearson Product Moment correlation while the reliability test uses Cronbach's Alpha. Test results show that all instruments are valid and reliable. The data analysis technique used in this study is descriptive statistical analysis.

\section{Result and Discussion}

The blended learning in this lecture uses e-learning system at Lambung Mangkurat University (ULM). Lecturers and students can access ULM e-learning using their respective SIMARI accounts. In this e-learning lecturer prepares lecture material, assignments to be completed by students, practice questions, and open discussion forums for each topic.

In the preparation stage, students are divided into groups. At this stage, students are informed that teaching materials consisting of lecture material, individual assignments and practice questions are uploaded to ULM elearning no later than three days before lecturing. Special practice questions can only be accessed by students when learning in the class. The students are also explained about the steps of learning.

Various obstacles are encountered when implementing learning. Based on observations, at the second meeting during the group discussion, learning process that should have been done face-to-face was not carried out, because there were still many students who did not read or access material uploaded in the ULM e-learning. Then, the lecturer must explain and repeat the material from beginning to the end.

Based on observations at the second meeting, then for the next meeting, students are required to download material from elearning, and must carry a hardcopy at the time of lecture. In addition, individual tasks in e-learning must be done and become a component for assessment. However, at the third meeting, there were still some students who did not have hardcopy of the material. In addition, despite having hardcopy of the material, many students have not studied the contents of the material. As a result, the group discussion at the third meeting was still not smooth. Based on this term, posttest and pretest are held for the next meeting. The following steps of learning carried out until the end of this study can be seen in Table 1 .

Table 2 shows that from the results of Quiz 1 to Quiz 3, students who received sufficient and good grades increased. In the final evaluation there was an increase in the percentage of students who scored less, but it was still below the percentage during Quiz 1 . Meanwhile based on the average value of the quiz results, there was an increase in learning outcomes. The average value of Quiz 1 with lacking qualifications increased to good qualifications in Quiz 3, and became sufficient qualification at the final evaluation.

The results showed that although the final test results were still in the sufficient category, there was an increase in quiz results from lacking to good. This is different from the results of research (Ismail, et all, 2014) which shows good learning outcomes in the application of blended learning in Computer Application courses. Various factors can affect learning outcomes, including motivation and learning activities.

The results also showed that students still needed encouragement to be actively involved in classroom learning and on-line learning. Although the lecture material is already available online, interview results show that only 51.5 percent of students stated that they studied the material before lecturing. 
Table 1. The Syntax of the Blended Cooperative Learning Model

\begin{tabular}{|c|c|c|}
\hline \multirow[t]{2}{*}{ Phase } & \multicolumn{2}{|c|}{ Activity } \\
\hline & e-learning & Classroom \\
\hline $\begin{array}{l}\text { Phase } 1 \\
\text { Presenting infor- } \\
\text { mation }\end{array}$ & $\begin{array}{l}\text { - Students learn material on-line } \\
\text { - Students completing assignments on-line }\end{array}$ & \\
\hline $\begin{array}{l}\text { Phase } 2 \\
\text { Delivering goals and } \\
\text { motivating students }\end{array}$ & carry out pretest & $\begin{array}{l}\text { The lecturer conveys the objectives to be } \\
\text { achieved and motivates students to } \\
\text { learn. }\end{array}$ \\
\hline $\begin{array}{l}\text { Fase } 3 \\
\text { Guiding work and } \\
\text { study groups }\end{array}$ & & $\begin{array}{l}\text { - The lecturers guide students to goups } \\
\text { up to discuss material that have been } \\
\text { done independently } \\
\text { - Students complete assignments in } \\
\text { groups } \\
\text { - The lecturers and students conclude } \\
\text { learning material }\end{array}$ \\
\hline $\begin{array}{l}\text { Phase } 4 \\
\text { Individual test }\end{array}$ & $\begin{array}{l}\text { The lecturer evaluates the learning out- } \\
\text { comes about the material that has been } \\
\text { learned }\end{array}$ & \\
\hline $\begin{array}{l}\text { Phase } 5 \\
\text { Give group awards }\end{array}$ & & $\begin{array}{l}\text { The lecturer gives an appreciation of the } \\
\text { efforts and results of group learning. }\end{array}$ \\
\hline
\end{tabular}

Table 3 presents the percentage of students' responses to learning. Only 56.7 percent of students stated that they became more independent in learning, and 54.6 percent said they could study material anywhere and anytime. Based on Table 3, the low involvement of students in accessing material seems related to the presentation of the online material. Therefore the lecturer must be able to choose which material can be easily studied and which should be presented in class. In addition, the material must be arranged in such a way that is more interesting and easy to understand. The majority of students feel enthusiastic, happy and interested in applying the blended cooperative learning model in introductory digital systems lectures. Overall students' perceptions of the application of the blended cooperative learning model showed a positive attitude.

In contrast to the results of research (Bala, 2016) and (Khan, 2014) which states that students are satisfied with the application of blended learning and feel motivated to practice subject matter in a more flexible and relaxed atmosphere outside the formal classroom. In this study, student activities in online learning activities are still low and students have not shown the desire to learn independently. This is in line with the results of research (Pramita, et all, 2018) in the implementation of blended learning in the Numerical Method course in the Computer Education Study Program at Lambung Mangkurat University. It is stated that students are not accustomed to learning independently. The results of this study also support the results of the 
study (Nuruzzaman, 2016), which states that lacked concentration and lack of participain blended learning the majority of students tion.

Table 2. Percentage Distribution of Student Learning Outcomes

\begin{tabular}{lcrrrc}
\hline \multicolumn{1}{c}{ Value } & Qualifications & Quiz 1 & Quiz 2 & Quiz 3 & Evaluation \\
\hline $75 \leq$ Value $\leq 100$ & Good & 25.3 & 19.8 & 52.7 & 40.7 \\
$60 \leq$ Value $<75$ & Sufficient & 0.0 & 25.3 & 29.7 & 33.0 \\
Value $<60$ & Lack & 74.7 & 54.9 & 17.6 & 26.3 \\
Average & & 36.2 & 57.0 & 75.4 & 70.1 \\
\hline
\end{tabular}

Table 3. Percentage Distribution of Student Responses

\begin{tabular}{rlrrrrr}
\hline No & Statement & SDA & DA & N & A & SA \\
\hline 1 & I am very enthusiastic in learning blended cooperative learning & 2.1 & 3.1 & 15.5 & 47.4 & 25.8 \\
& activities & & & & & \\
2 & I feel happy when in learning with blended cooperative learning & 1.0 & 1.0 & 23.7 & 36.1 & 32.0 \\
3 & I am very interested in the material presented online & 1.0 & 3.1 & 24.7 & 37.1 & 27.8 \\
4 & the time given to study the material online is sufficient & 4.1 & 18.6 & 25.8 & 28.9 & 16.5 \\
5 & With blended learning I can study material wherever and whenever & 3.1 & 11.3 & 26.8 & 26.8 & 25.8 \\
6 & Learning material provided online is easy to understand & 1.0 & 5.2 & 33.0 & 40.2 & 14.4 \\
7 & with blended learning, making me more independent in learning & 3.1 & 7.2 & 33.0 & 29.9 & 20.6 \\
\hline
\end{tabular}

Based on several findings in this study, it seems that students still have to be encouraged to access all material that is already available on-line and study it independently. Some additional treatment can be done including requiring students to download the material and file it in hardcopy, make a resume of the material they learn, compile questions that will be discussed in group discussions, include on-line assignments as a component of assessment, or do a pretest at each face advance in class. To avoid plagiarism, some assignments required students to do them by hand writing. Through this kind of assignment, students will experience the learning process.

\section{Conclusion}

The results showed that whilst there was an increase, student learning outcomes were still in the sufficient category. In addition students have a positive perception of the application of the blended cooperative learning model. However, although independent learning is important, it seems that students still need more encouragement to increase their learning independence.

\section{References}

Aspden, L., \& Helm, P. (2004). Making the connection in blended learning environment. Educational Media International, 42, 245-252.

Bala, E. (2016). A study of attitudes of students towards blended learning, Iraqi Case. International Journal of Social Sciences \& Educational Studies, 2 (4).

Dziuban, C., Graham, C. R., Moskal, P. D., Norberg, A., \& Sicilia, N. (2018). Blended learning: the new normal and emerging technologies. International Journal of Educational Technology in Higher

Education. https://doi.org/10.1186/s41239-0170087-5

EL-Deghaidy, H., \& Nouby, A. (2008). Effectiveness of a blended e-learning cooperative approach in an Egyptian teacher education programme. Computers and Education. 
https://doi.org/10.1016/j.compedu.2007. 10.001

Gill, D. (2009). Effective Blended Learning Techniques. Journal of College Teaching \& Learning (TLC), 6(2). https://doi.org/10.19030/tlc.v6i2.1167

Graham, C. R. (2006). Introduction to Blended Learning. Handbook of Blended Learning Global Perspectives Local Designs.

https://doi.org/10.2307/4022859

Hall, S., \& Villareal, D. (2015). The Hybrid Advantage: Graduate Student Perspectives of Hybrid Education Courses. International Journal of Teaching and Learning in Higher Education.

Hima, L. R. (2017). Pengaruh Pembelajaran Bauran (Blended Learning) terhadap Motivasi Siswa pada Materi Relasi dan Fungsi. JIPMat, 2 (1). https://doi.org/10.26877/jipmat.v2i1.14 79

Husamah. (2014). Pembelajaran Bauran (Blended Learning). Jakarta: Pustakakarya.

Ismail, N., WanZah Wan Ali, Aida Suraya Mod Yunus, \& Ayub, A. F. M. (2014). The effects of blended learning methods on educational achievement and the development of online material in a Curriculum Information Document Online System (CIDOS) for computer application courses. Malaysian Journal of Distance Education, 16 (2). pp. 59-82

Khan, I. A. (2014). Effectiveness of blended learning for teaching of English: An exploratory study. Research Journal of Recent Sciences, 3 (3).

López-Pérez, M. V., Pérez-López, M. C., \& Rodríguez-Ariza, L. (2011). Blended learning in higher education: Students' perceptions and their relation to outcomes. Computers and Education, 56 (3).

https://doi.org/10.1016/j.compedu.2010.
10.023

Meydanlioglu, A. \& Arikan, F. (2014). Effect of Hybrid Learning in Higher Education. International Journal of Social, Behavioral, Educational, Economic, Business and Industrial Engineering, 8 (5).

Moskal, P., Dziuban, C., \& Hartman, J. (2013). Blended learning: A dangerous idea? Internet and Higher Education. https://doi.org/10.1016/j.iheduc.2012.12 .001

Nuruzzaman, A. (2016). The Pedagogy of Blended Learning: A Brief Review. IRA International Journal of Education and Multidisciplinary Studies (ISSN 24552526),

4(1). https://doi.org/10.21013/jems.v4.n1.p14

Pramita, M., Sukmawati, R. A., \& Sari, D. P. (2018). The Implementation of Flipped Classroom Assisted by Learning Management System for Numerical Method Courses. https://doi.org/10.2991/iccite18.2018 .36

Rusman. (2012). Model-model Pembelajaran. Jakarta: Raja Grafindo.

Slavin, R. (1994). Educational Psychology, Theory and Practice. Massachussets: Allyn and Bacon.

Sukmawati, R. A., \& Nesvihani, N. (2018). Kemampuan komunikasi matematis dan karakter tanggung jawab siswa dalam implementasi model pembelajaran kooperatif tipe quick on the draw di kelas VIII. EDU-MAT, 6(1). Retrieved from https://ppjp.ulm.ac.id/journal/index.php/ edumat/article/view/5120

Sukmawati, R. A., \& Purnamasari, W. (2016). Pembelajaran matematika menggunakan model pembelajaran kooperatif tipe teams games tournaments (TGT) di Kelas VIII SMP. EDU-MAT, 4(1). Retrieved from https://ppjp.ulm.ac.id/journal/index.php/ edumat/article/view/2293 